\section{AUTHOR}

FRANCISCO J. LÓPEZ-ARCEIZ

Institute for Advanced Research in Business and Economics

Public University of Navarra

francisco.lopez@unavarra.es

LOURDES TORRES

Department of Accounting and Finance

University of Zaragoza

Itorres@unizar.es

\section{ANA J. BELLOSTAS}

Department of Accounting and Finance

University of Zaragoza

bellosta@unizar.es

\title{
Does Online Accessibility, as a Transparency Mechanism, Play the Same Role in Private and Public Nonprofit Organizations?
}

\section{ABSTRACT}

Nonprofit organizations define different links with Public Administration in the provision of public social services, online accessibility (OA) being a way to promote stakeholders' participation and funding diversification. Despite these theoretical advantages, the role of OA could vary depending on the interaction between Public Administration and nonprofits. If these organizations identify OA only with accountability, a passive meaning of transparency will prevail. By contrast, when nonprofits understand this mechanism as a strategic tool, it become an organizational resource to promote stakeholders' feedback and higher levels of performance. The results show differences between private and public nonprofits when they promote OA.

\section{KEY-WORDS}

ONLINE ACCESSIBILITY, TRANSPARENCY, ACCOUNTABILITY, STRATEGIC TOOL, NONPROFIT ORGANIZATIONS

\section{Acknowledgments}

This study has been carried out with the support of the Ministry of Economy and Competitiveness (Ref- ECO201566240-P/ECO2016-77631- R). 


\section{Introduction}

The European Union and the member states have promoted transparent practices, as online accessibility, in different sectors and, in particular, in nonprofit organizations that provide public services (Brinkerhoff, 2002; TFEU, 2012). These entities are an essential channel to decentralization and privatization of some public services (Overman and Van Thiel, 2016). They emerged as a way (...) to increase the role of government in promoting the general welfare without unduly enlarging the state's administrative apparatus (Salamon, 1987).

The links between the public sector and nonprofits can be defined by two basic relationship models (Sarasa and Moreno, 1995; Van Thiel, 2012; Overman and Van Thiel, 2016): the collaborative model and the subordinate model. In the model based on collaborative relationships, private nonprofits channel social demands. They play an active role in the development of social policies and are open to the participation of users and stakeholders. In the model based on subordinate relationships, public nonprofits are functional extensions of governments and, thus, work as public agencies. This relationship is characterized by a strong financial control, the support from the government and a little participation and integration of other involved agents (Kuhnle and Selle, 1990; Henriksen, 2007; Verschuere and De Corte, 2015). In Europe, both models of relationship are detected. For example, in southern European countries, such as Portugal, Italy and Spain, a strong interaction between governments and nonprofits is observed (Evers and Laville, 2004; Salamon and Sokolowski, 2014). In contrast, in the Anglo-saxon and Nordic countries, some public services are provided by private nonprofits, which are funded by private stakeholders (Sarasa and Moreno, 1995).

Depending on the model of relationship, transparent practices will play a different role as a response to different stakeholders' needs. Transparent practices are defined as the availability of organizational specific information to those outside the entity (Bushman, Piotroski and Smith, 2004). Transparency cannot be measured directly, but it can be perceived from the level of communication achieved (Bushman et al, 2004: 211), the level of online accessibility through the organizational website being a tool of communication (López-Arceiz, Bellostas and Rivera, 2017: 37).

The objective of this paper is to test whether the online accessibility, as a tool of transparency, is a synonym for accountability or a strategic tool to integrate stakeholders in a sample of nonprofits that belongs to a specific southern European country. To do so, we analyse the use of online accessibility in Spanish public and private nonprofits. Our results show that the role of online accessibility varies depending on the type of relationship between nonprofits and governments and the origin of their financial resources. The results of this study could be useful to the managers and other stakeholders of nonprofits in countries with a similar provision of social services. In this sense, the online accessibility is an opportunity to promote an active stakeholders' participation and to achieve higher levels of financial diversification. 
This paper is organized as follows. In Section 2, the literature review and our working hypothesis are established. In Section 3, the methodology, data, variables and descriptive statistics are described. Section 4 presents the results and Section 5 discusses them. Finally, Section 6 provides the main conclusions obtained in the study.

\section{Online accessibility in relationships between nonprofits and governments}

Nonprofit organizations works together with governments in developed countries to provide social services that enhance social welfare, establishing links of different natures. These entities have gained legitimacy for the provision of social services in Spain, while the government have reduced their role as direct suppliers through delegation. This relationship is characterized by financial interdependence and collaboration, with no competition between the two agents (Salamon, 1987; Kramer, 1992). Foundations, as nonprofit organizations, and the Spanish government make up a mixed model of social services provision, based on contractual links between the public and the private sectors which are defined by subordination (public initiative) or collaborative criteria (private initiative) in decision making. The degree of subordination or dependence in the relationship between foundations and governments determines the type of foundation, public or private. Public foundations maintain the highest level of subordination, while private foundations have more autonomy in their decision-making processes. Anyway, both of them are regulated by the same legal framework (Foundation Act - Ley 50/2002, de Fundaciones), being the only difference the public/private promotor and the origin of their funding (López-Arceiz, Torres and Bellostas, 2019). Currently, the Spanish legal framework for these entities establishes accountability processes as a key element. These processes have recently been completed and enriched by the voluntary online accessibility, as a transparency tool (López-Arceiz, Bellostas and Rivera, 2017).

There are many studies that show the advantages of the promotion of online accessibility in organizations: a) Obtaining social legitimacy among stakeholders (Ball, 2009; Kosack and Fung, 2014; Saxton et al., 2014), b) Creating trust between them and enhance appropriate funding decisions (Tinkelman, 1999; Gandía, 2008; 2011; Trussel and Parsons, 2008; Khumawala, Neely and Gordon, 2010), c) Promoting of stakeholder participation (Saxton and Guo, 2011), and d) Reducing problems relate to asymmetric information, such as inefficient resource allocations and agency issues (Behn, DeVries and Lin, 2010).

Despite the advantages related to the use of online accessibility, its role has not been analysed, especially in the nonprofit context. Some authors consider online accessibility as an accountability tool and a logical consequence of the development of the norms and regulations of a society (Gandía, 2008; 2011; Ball, 2009; Kosack and Fung, 2014; Schnackenberg and Tomlinson, 2014). Its development responds to political impositions, mimicking other entities, or the professionalization of organizational structure (López-Arceiz, Bellostas and Rivera, 2017). In contrast, other authors have considered online accessibility as a strategic element, a tool of disclosure and good governance (Aras 
and Crowter, 2008), which is able to integrate external stakeholders in decision-making processes (Haveri, 2006; Aras and Crowter, 2008). In this context, online accessibility is a communication channel that provides organizational information and enhances stakeholder trust and participation (Gallego-Álvarez, García-Sánchez and Rodríguez-Domínguez, 2008).

The type of interaction between nonprofits and governments can influence the role of online accessibility in a nonprofit organization (Sarasa and Moreno, 1995; Basu et al., 2012). Rosenthal and Newbrander (1996) and Berendes et al. (2011) propose that private nonprofits may be more participative and responsive to users' needs than subordinate or public nonprofits, online accessibility being an element to strengthen collaborative relationships. In this sense, private nonprofits would need to create higher levels of trust to achieve funding and users (GálvezRodríguez, García-Sánchez and Rodríguez-Domínguez, 2014; Saxton, Neely and Guo, 2014). However, these proposals have not been empirically tested in spite of the different roles that online accessibility can play in the processes of integration of stakeholders. As a consequence, we propose our hypothesis,

$H_{1}$ : The public or private character of a nonprofit organization conditions the role of online accessibility on the interaction between resources and organizational achievements.

The non-rejection of this hypothesis will imply that private nonprofits have a different behaviour, characterized by the development of transparency mechanisms, as online accessibility, in order to attain a better functioning of the entity in terms of performance, financial diversification and participation of stakeholders (Myers and Sacks, 2003; Arnaboldi and Lapsley, 2004; Dart, 2004;). Then, in this case, online accessibility plays an active role, a feedback being provided between the nonprofit and its stakeholders. On the other hand, public nonprofits, characterized by their strong dependence on governments, will be defined by the low motivation of their members to introduce online accessibility and to promote the external participation in line with Dolnicar, Irvine and Lazarevski (2008) and Blackwood (2012). Consequently, these entities will consider online accessibility as a passive communication tool where they are able to share information, but without obtaining any kind of feedback. However, the rejection of this hypothesis would agree with the conclusions of Funnell and Cooper (1998), Irvine (2000) and Josserand, Teo and Clegg (2006) who proposed that the role of online accessibility, as a dimension of transparency, is the same for public and private nonprofits. This may be due to the increase in legal standards and the development of monitoring mechanisms in modern societies (Sutheewasinnon, Hoque and Nyamori, 2016).

Figure 1 shows the theoretical model that is the basis for the hypothesis proposed in this paper. The squares connected by arrows show the possible paths (Path 1: Economic and financial resources $\rightarrow$ Online accessibility $\rightarrow$ Organizational achievements; Path 2: Human resources $\rightarrow$ Online accessibility $\rightarrow$ Organizational achievements). The public or private character of the nonprofit organization is considered a moderator variable. 
Figure 1. Theoretical model and working hypothesis

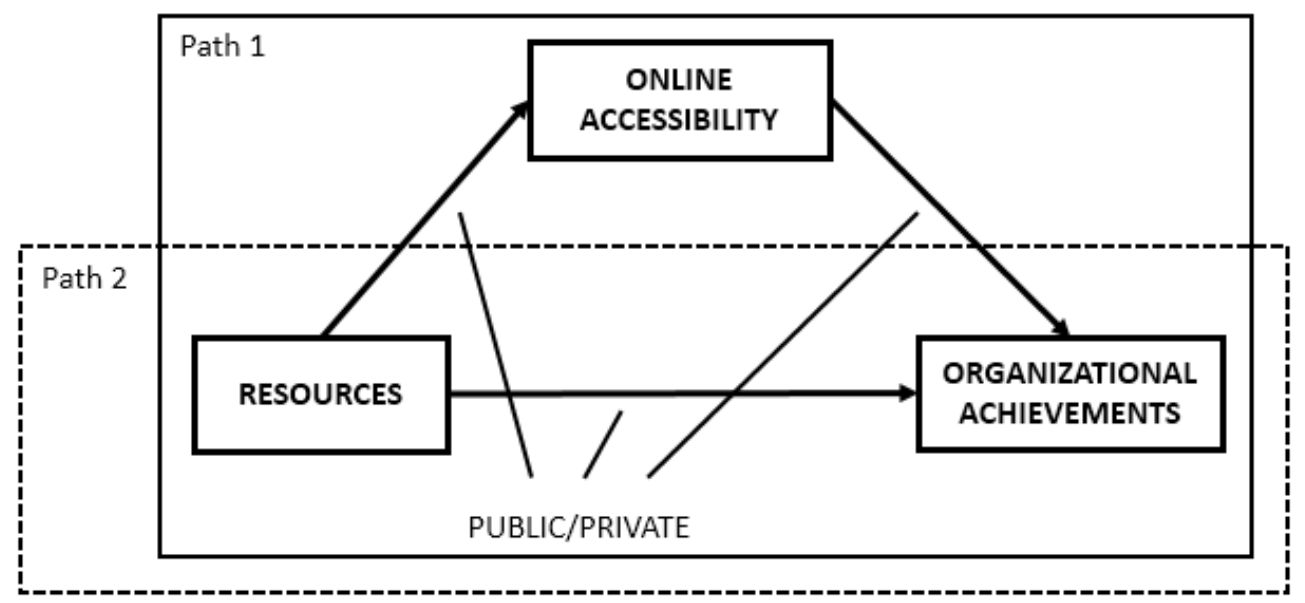

Path 1: Economic and financial resources $\rightarrow$ Online accessibility $\rightarrow$ Organizational achievements

Path 2: Human resources $\rightarrow$ Online accessibility $\rightarrow$ Organizational achievements

\section{Methodology}

\subsection{Sample and main variables}

To test our hypothesis, we have analysed the financial statements and audit reports of 153 Spanish public nonprofits for 2012 and $2015^{1}$. These entities are foundations that develop a public social services. Their legal regime is developed by the foundations act (Ley 50/2002, de Fundaciones) and the public administration act (Ley 40/2015, de Regimen Juridico del Sector Público). The Spanish case presents some singularities that recommend its study. First, these entities are responsible for the provision of some social services in Spain. Second, these entities were pressured to disclose information by the Spanish legal and accounting framework. In this sense, the consideration as public nonprofits implies the adoption of online reporting mechanisms in the context of the transparency act (Ley 19/2013, de transparencia). Finally, online mechanisms favours alternative methods of funding. This information was obtained from the Ministry of Justice and the Departments of Justice of the regional governments, as well as from the web of Transparency of the Central and Regional Governments. Moreover, we obtained a control sample of Spanish private nonprofits with similar characteristics of size, location and activity. Table 1 presents the main characteristics of the total sample.

According to the Spanish government, there was a population of 397 public nonprofits in the analysed period. We used simple random sampling to select the sample. Sample size was calculated for a $6.2 \%$ error for global results and a $95 \%$ confidence interval, using a conservative approach $(\mathrm{p}=\mathrm{q}=0.5)$. 
Table 1. Description of the Sample

\begin{tabular}{|c|c|c|}
\hline Variable & Description & \\
\hline \multirow[t]{3}{*}{ Size } & Small (Less than 50 workers) & $73.80 \%$ \\
\hline & Medium (Between 50 and 250 workers) & $23.30 \%$ \\
\hline & Large (More than 250 workers) & $2.90 \%$ \\
\hline \multirow[t]{2}{*}{ Sphere } & State & $42.00 \%$ \\
\hline & Regional & $58.00 \%$ \\
\hline \multirow[t]{7}{*}{ Service Aim } & Health Services & $72.00 \%$ \\
\hline & Cooperation and Development Action & $25.43 \%$ \\
\hline & Social Services & $1.14 \%$ \\
\hline & Religious Activities & $0.57 \%$ \\
\hline & Trade Union Action & $0.29 \%$ \\
\hline & Education Promoting & $0.29 \%$ \\
\hline & Cultural Activities & $0.29 \%$ \\
\hline \multirow{7}{*}{$\begin{array}{l}\text { Number of users } \\
\text { (mean by organization) }\end{array}$} & Health Services & $3,737.83$ \\
\hline & Cooperation and Development Action & $5,539.15$ \\
\hline & Social Services & $4,989.08$ \\
\hline & Religious Activities & - \\
\hline & Trade Union Action & $69,703.00$ \\
\hline & Education Promoting & $35,015.38$ \\
\hline & Cultural Activities & $35,019.38$ \\
\hline
\end{tabular}

In general terms, Spanish public nonprofits are small with respect to their number of employees. These entities carry out their activity in two spheres, national and regional, although we can observe a more intensity at regional level. Finally, these organizations work in a wide range of sectors, from health to culture. In relation to the number of users by organization, we observe that trade union, educations and cultural activities maintain a high number of users, while health and social services have a low number of users in comparison.

The theoretical model proposed identifies three categories of variables: resources, online accessibility and organizational achievements. They cannot be measured directly (Moneva and Ortas, 2010) and it is necessary to formulate indicators for these dimensions. 


\subsubsection{Resources}

Scott (2003), Anheier (2014) and Carnochan at al. (2014) study the predominance of economic, financial and human resources in a nonprofit organization. For the measurement of economic and financial resources, we have chosen cash and cash-equivalent, equity, non-current liability and activity grants according to Torres and Pina (2003) and Schneider and Hagleitner (2005). Regarding human resources, the number of workers, staff expenses and working hours have been selected in line with Neumayr, Schneider and Meyer (2013), Kang, Huh, Cho and Auh (2014), Hamann and Foster (2014) and Becchetti, Castriota and Depedri (2014).

\subsubsection{Online accessibility}

Some authors state that an entity is accessible if it voluntarily discloses information on the Internet (Gandía, 2011; Saxton et al., 2014; Gandía, Marrahí and Huguet, 2016). This study assesses online accessibility through two indicators: Depth and breadth of the website. Both indicators are based on the level of accessibility to specific information, the financial statements and to the audit report of nonprofits. The first indicator is an ordinal variable to show the number of clicks needed to get to the information available online. The number of clicks has been used as a proxy of online accessibility by several authors (Glassey and Glassey, 2004; Anthopoulos and Sikarukis, 2015; López-Arceiz, Bellostas and Rivera, 2017). This variable is based on 3-clicks rule proposed by Zeldman (2001) and it defines a tolerance threshold, based on experimental psychology, in the mean Internet user (Glassey and Glassey, 2004). For the entities that do not have a webpage, the value was codified as 0 . Entities frequently provide new information while eliminating previous information, which can make it difficult to track the evolution of the activities of the organization. This second indicator of accessibility is known as breadth of a website (Zaphiris and Mtei, 1997) and it is based on the information provided by the organization. We have chosen the number of years that the entity has its published financial statements and made its audit reports available. A quantitative variable represents the number of years with information available. The value 0 indicates that there is no information.

\subsubsection{Organizational achievements}

Nonprofit organizations tend to adopt business practices, progressively evolving towards the hybrid prototype of social enterprises. Although academia has not reached a consensus on the concept of social enterprises, there is a common denominator among the different schools: the identification as an entity that gathers both social and economic objectives in its business strategies (Emerson, 2006; Porter et al., 2012; Bellostas, López-Arceiz and Mateos, 2016). Profit achievements must be considered as an indicator of performance due to the fact that they guarantee the financial survival of the organization. Of course, the measurement of performance for these entities should be completed with additional indicator related to social performance. Consequently, indicators for both economic and social achievements have been taken into 
account. Within the economic achievements, we can assess three different aspects: economic performance and private and public fund raising. In this work, the assessment of economic performance is based on the following indicators: operating income, earnings before taxes and net profit. The classification of the raising of funds, or the volume of resources obtained by the entity, follows the proposals of Hungerman (2005), Sieg and Zhang (2012) and Andreoni and Payne (2013) who classify funding sources based on their origin. At the private level, donations of individuals, financial entities and nonprofits have been chosen while, at the public level, state and regional grants have been selected. The social activity of nonprofit organizations is not directly measurable, so the participation of users has been chosen as a proxy of the creation of social value through generated outputs ${ }^{2}$.

\subsection{Data Analysis}

A descriptive analysis of the variables is carried out using exploratory analysis techniques. After the evaluation of the covariance matrix, a confirmatory factor analysis examines the dimensional structure of the theoretical constructs involved in our hypothesis (resources, online accessibility and organizational achievements) and factor scores are obtained (Fornell and Larcker, 1981; McDonald, 1989). In order to test the hypothesis, the results of the structural equation models are evaluated. In these models, the indirect effect of online accessibility on the relationship between resources and organizational achievements is analysed. Figure 2 shows the specification for the whole model. It possible to observe that eight latent variables have been estimated together with the structural model.

2 This measurement criterion is defined by the Spanish legal framework (Memoradum Circular-Resolución de 26 de marzo de 2013: BOE no. 85 de 9 de Abril de 2013 and Memoradum Circular-Resolución de 26 de marzo de 2013: BOE no. 86 de 10 de Abril de 2013). This criterion has also been used recently by different authors such as Mano (2014; 2015); Bellostas, López-Arceiz and Mateos (2016); López-Arceiz, Bellostas and Rivera (2017). 
Figure 2. Model specification. LISREL notation

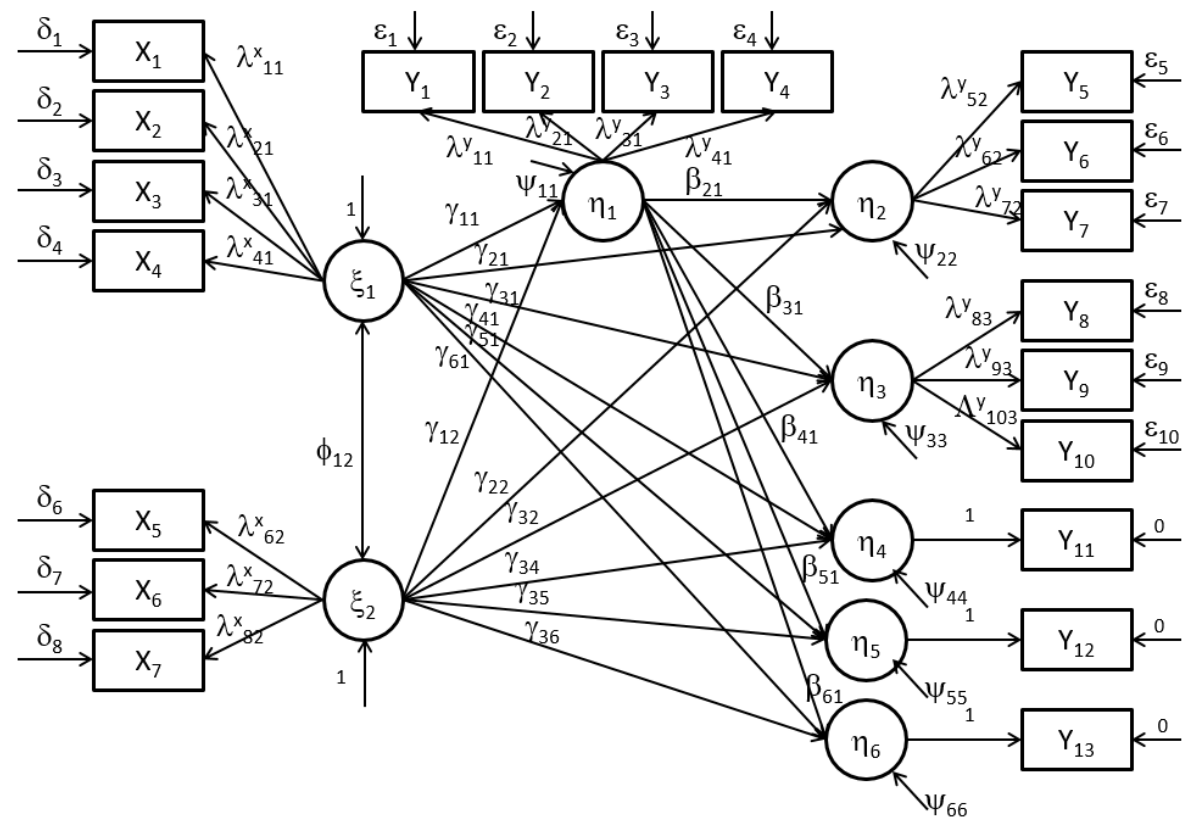

\begin{tabular}{|c|c|c|c|}
\hline Latent variable & Abbreviation & Indicator & Abbreviation \\
\hline \multirow{4}{*}{ Online Accessibility } & \multirow{4}{*}{$\eta_{1}$} & Financial Statements Accessibility & $Y_{1}$ \\
\hline & & Financial Audit Accessibility & $\mathrm{Y}_{2}$ \\
\hline & & Financial Statements Depth & $\mathrm{Y}_{3}$ \\
\hline & & Financial Audit Depth & $\mathrm{Y}_{4}$ \\
\hline \multirow{3}{*}{ Economic Performance } & \multirow{3}{*}{$\eta_{2}$} & Operating income & $\mathrm{Y}_{5}$ \\
\hline & & Earnings before taxes & $\mathrm{Y}_{6}$ \\
\hline & & Net Profit & $\mathrm{Y}_{7}$ \\
\hline \multirow{3}{*}{ Private Funding } & \multirow{3}{*}{$\eta_{3}$} & Don. Individuals & $\mathrm{Y}_{8}$ \\
\hline & & Don. Financial Entities & $\mathrm{Y}_{9}$ \\
\hline & & Don. Nonprofits & $Y_{10}$ \\
\hline State Funding & $\eta_{4}$ & State Funding & $Y_{11}$ \\
\hline Regional Funding & $\eta_{5}$ & Regional Funding & $Y_{12}$ \\
\hline Social Performance & $\eta_{6}$ & Social Performance & $Y_{13}$ \\
\hline \multirow{4}{*}{ Financial Resources } & \multirow{4}{*}{$\xi_{1}$} & Cash and cash-equivalent & $\mathrm{X}_{1}$ \\
\hline & & Equity & $\mathrm{X}_{2}$ \\
\hline & & Non-Current Liability & $\mathrm{X}_{3}$ \\
\hline & & Activity Grants & $\mathrm{X}_{4}$ \\
\hline \multirow{3}{*}{ Human Resources } & \multirow{3}{*}{$\xi_{2}$} & Workers & $\mathrm{X}_{5}$ \\
\hline & & Personal Expenses & $X_{6}$ \\
\hline & & Working Hours & $\mathrm{X}_{7}$ \\
\hline
\end{tabular}


The public or private character of the nonprofit is introduced as a moderating variable in this relationship (Preacher et al., 2007; Hayes, 2013). The moderating effect of this variable is analysed through a multi-group approach. This statistical approach enabled us to obtain, test and estimate measurements and/or structural models based on robust statistics with multivariate non-normality and non-independence of observations. This methodology is suitable when there are no latent variables with formative indicators, such as online accessibility (López-Arceiz, Bellostas and Rivera, 2017; López-Arceiz, Torres and Bellostas, 2019) and a mediation model is specified (Preacher and Hayes, 2007). For this reason, we have considered this methodology as the most suitable tool for the aim of this work (Satorra and Bentler, 2001; Bentler, 2006; Muthén and Muthén, 1998-2015). This study made use of the MPLUS 7.4 and EQS 6.2 software (Bentler, 2006; Muthén and Muthén, $1998-2015)^{3}$.

\section{Results}

The descriptive statistics provide a first approximation to the variables and relationships under study. As can be seen in Table 2, the entities in the sample have, in terms of their resources, a solid financial position and employ an average of 167.79 workers. With respect to online accessibility, as a transparent practice, these entities show accessible information in terms of depth, although the majority only provide information about the previous year. These nonprofits show a positive economic performance, with a high dependence on public funding. In relation to the social activity, a high level of users is observed.

\footnotetext{
3 The estimation method was Maximum Likelihood with Robust Standard Errors and the Chi-Square Test Statistic (MLR) estimation methods obtained by using the TYPE=COMPLEX option (Muthén and Muthén 1998-2015). At the same time, in order to evaluate the global fit, we present different goodness of fit statistics and indexes (Robust statistic $\varkappa^{2}$, Root Mean Square Error of Approximation (RMSEA), Standardised Root Mean Square Residual (SRMR) and Comparative Fit Index (CFI) (Bollen, 1989).
} 


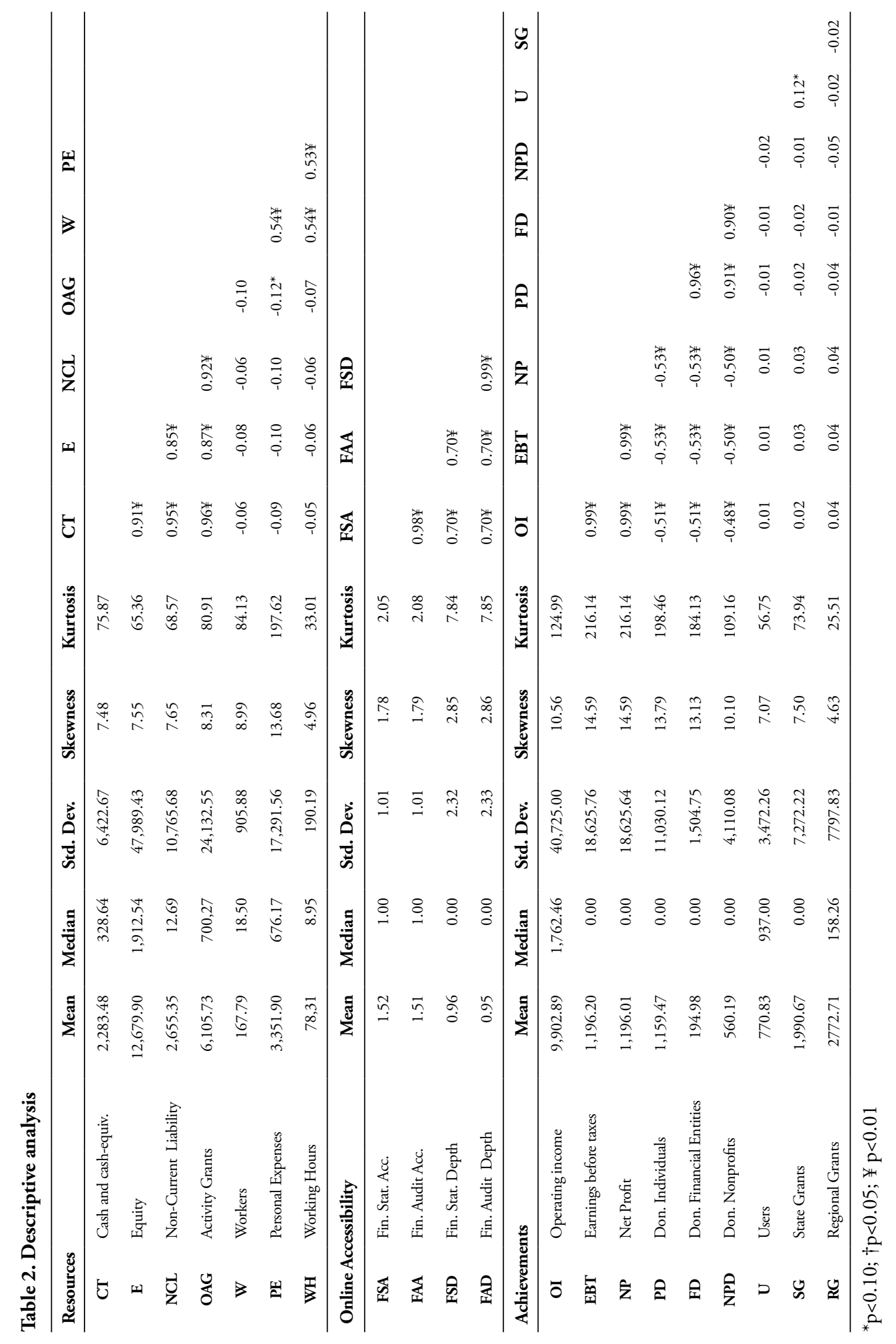


Table 2 also shows a high heteroscedasticity, positive skewness and leptokurtosis in the studied sample. For these reasons, we have relativized these variables depending on the level of operation earnings of these entities (Marcuello and Salas, 2001) and we have used robust estimators to study the interaction between the different indicators. Moreover, Table 2 presents the correlations matrix between the different indicators. The correlations matrix shows the existence of five possible latent dimensions because of the high correlations observed. Tables 3 and 4 show the measurement and the structural model, respectively. The measurement model shows an acceptable fit for the whole sample $\left(\boldsymbol{x}^{2}{ }_{(10)}\right.$ : 7.774, pvalue: 0.651, RMSEA: 0.001, SRMR: 0.004 and CFI: 0.999), which allows us to assess the specified models. The proposed dimensions also present a reasonable individual fit (Average Variance Extracted-AVE and Composite Reliability CoefficientCRC). The resources of the nonprofits are observed from both the economic and financial point of view (factor loadings-[0.911-0.997]) and from the human resources point of view (factor loadings-[0.719-0.743]). The depth and breadth of the economic and financial information are indicators of online accessibility (factor loadings [0.710-0.991]). The achievements of the entity consist of two latent dimensions, economic performance (factor loadings-[0.998-0.999]) and private funding (factor loadings-[0.924-0.981]), as well as three indicators, state funding, regional funding and social performance, which are introduced into the structural model with a zero measurement error (Bollen, 1989).

Having analysed the goodness of fit and the results of the measurement model, the results obtained for the structural model can be assessed. In Table 4, the first path analyses the relation between economic/financial resources and organizational achievements through the online accessibility variable. We can observe that there is no indirect effect between them (0.000; pvalue $>0.100)$. 
Table 3. Measurement Model

\begin{tabular}{|c|c|c|c|c|c|}
\hline & Estimate & Std. Dev & $\mathbf{R}^{2}$ & AVE & CRC \\
\hline \multicolumn{6}{|l|}{ Resources } \\
\hline \multicolumn{6}{|c|}{ Financial Resources by } \\
\hline Cash and cash-equivalent & $0.997 ¥$ & 0.005 & 0.995 & 0.910 & 0.954 \\
\hline Equity & $0.911 ¥$ & 0.089 & 0.829 & & \\
\hline Non-Current Liability & $0.948 ¥$ & 0.053 & 0.899 & & \\
\hline Activity Grants & $0.958 ¥$ & 0.043 & 0.917 & & \\
\hline \multicolumn{6}{|c|}{ Human Resources by } \\
\hline Workers & $0.743 ¥$ & 0.147 & 0.448 & 0.466 & 0.731 \\
\hline Personal Expenses & $0.719 ¥$ & 0.163 & 0.483 & & \\
\hline Working Hours & $0.731 ¥$ & 0.093 & 0.466 & & \\
\hline
\end{tabular}

Transparency Mechanism

\section{Online Accessibility by}

Financial Statements Accessibility

\begin{tabular}{lllll}
$0.989 ¥$ & 0.010 & 0.977 & 0.743 & 0.851 \\
$0.991 ¥$ & 0.004 & 0.981 & & \\
$0.710 ¥$ & 0.045 & 0.504 & & \\
$0.713 ¥$ & 0.044 & 0.508 & & \\
\hline
\end{tabular}

Financial Audit Accessibility

Financial Statements Depth

\section{Achievements}

\section{Economic Performance by}

\begin{tabular}{|c|c|c|c|c|}
\hline Operating income & $0.998 ¥$ & 0.002 & 0.995 & 0.997 \\
\hline Earnings before taxes & $0.999 ¥$ & 0.001 & 0.998 & \\
\hline Net Profit & $0.999 ¥$ & 0.000 & 0.999 & \\
\hline
\end{tabular}

Private Funding by

\begin{tabular}{llllll} 
Don. Individuals & $0.981 ¥$ & 0.020 & 0.962 & 0.924 & 0.961 \\
Don. Financial Entities & $0.978 ¥$ & 0.024 & 0.957 & & \\
Don. Nonprofits & $0.924 ¥$ & 0.074 & 0.853 & & \\
\hline
\end{tabular}

\begin{tabular}{llllll}
\hline State Funding & 1.000 & - & - & - & - \\
\hline Regional Funding & 1.000 & - & - & - & - \\
\hline Social Performance & 1.000 & - & - & - & - \\
\hline
\end{tabular}

${ }^{*} \mathrm{p}<0.10 ; \dagger \mathrm{p}<0.05 ; ¥ \mathrm{p}<0.01$ 


\begin{tabular}{|c|c|c|c|c|c|}
\hline & $\begin{array}{l}\text { Financial } \\
\text { Resources }\end{array}$ & $\begin{array}{r}\text { Human } \\
\text { Resources }\end{array}$ & $\begin{array}{r}\text { Online } \\
\text { Accessibility }\end{array}$ & $\mathbf{R}^{2}$ & Goodness Fit \\
\hline \multicolumn{6}{|l|}{ Direct Effects } \\
\hline Online Accessibility & 0.001 & 0.034 & - & 0.001 & \multirow{12}{*}{$\begin{array}{c}x 2[10]: 7.774, \\
\text { pvalue: } 0.651, \\
\text { RMSEA: } 0.001 \text {, } \\
\text { SRMR: } 0.004, \\
\text { CFI: } 0.999\end{array}$} \\
\hline Economic Performance & $-0.997 ¥$ & $-0.036^{*}$ & $0.008 ¥$ & 0.990 & \\
\hline Private Funding & $0.992 ¥$ & -0.007 & $0.007 ¥$ & 0.984 & \\
\hline State Funding & $-0.036 ¥$ & -0.098 & $-0.088 \dagger$ & 0.019 & \\
\hline Regional Funding & $-0.033 ¥$ & -0.027 & 0.002 & 0.002 & \\
\hline Social Performance & $-0.018 ¥$ & 0.017 & 0.037 & 0.002 & \\
\hline Indirect Effects & & & & & \\
\hline Economic Performance & 0.000 & 0.000 & & & \\
\hline Private Funding & 0.000 & 0.000 & & & \\
\hline State Funding & 0.000 & -0.003 & & & \\
\hline Regional Funding & 0.000 & 0.000 & & & \\
\hline Social Performance & 0.000 & 0.001 & & & \\
\hline
\end{tabular}

${ }^{*} \mathrm{p}<0.1 ; \dagger \mathrm{p}<0.05 ; ¥ \mathrm{p}<0.01$

This result could be explained by the lack of a direct relation between economic/financial resources and online accessibility (0.001; pvalue $>0.100)$. In other words, the observed lack of indirect effect is caused by the non-existence of a significant effect between economic/financial resources and online accessibility. The second path studies the mediating role of online accessibility in the relationship between human resources and organizational achievements. The lack of an indirect effect through online accessibility can again be observed (parameters [-0.003; 0.001]; pvalue>0.100). The reason behind this result is the nonsignificance of the direct effect between human resources and online accessibility (0.034; pvalue>0.100). This result implies that the online accessibility does not have a positive mediating effect on the relation between resources and organizational achievements. Nevertheless, we can observe direct effects between online accessibility and some dimensions of achievements, such as economic performance $(0.008$; pvalue $<0.010)$ and private funding $(0.007$; pvalue $<0.010)$.

This result could be influenced by the public or private character of the nonprofit, which may condition the role of online accessibility in the previous relationships. Table 5 shows the results of the estimations in the different subsamples. The fit of the subsamples of private $\left(x^{2}{ }_{(10)}: 21.393\right.$, pvalue: 0.019, RMSEA: 0.068, SRMR: 0.078, CFI: 0.911) and public nonprofits $\left(\varkappa_{(10)}^{2}: 11.403\right.$, pvalue: 0.327, RMSEA: 0.038, SRMR: 0.043, CFI: 0.955) shows an acceptable value, which allows us to assess the different parameters. 
Table 5. Multigroup Analysis

\begin{tabular}{|c|c|c|c|c|c|}
\hline & \multicolumn{5}{|c|}{ Private Group (N=73) } \\
\hline & $\begin{array}{l}\text { Financial } \\
\text { Resources }\end{array}$ & $\begin{array}{l}\text { Human } \\
\text { Resources }\end{array}$ & $\begin{array}{c}\text { Online } \\
\text { Accessibility }\end{array}$ & $\mathbf{R}^{2}$ & Goodness Fit \\
\hline \multicolumn{6}{|l|}{ Direct Effects } \\
\hline Online Accessibility & $-0.105 ¥$ & 0.087 & & 0.022 & \multirow{12}{*}{$\begin{array}{c}x 2[10]: 21.393, \\
\text { pvalue: } 0.019, \\
\text { RMSEA: } 0.068 \text {, } \\
\text { SRMR: } 0.078 \text {, } \\
\text { CFI: } 0.911\end{array}$} \\
\hline Economic Performance & $-0.998 ¥$ & $-0.013 ¥$ & 0.005 & 0.998 & \\
\hline Private Funding & $0.997 ¥$ & -0.007 & 0.006 & 0.996 & \\
\hline State Funding & $-0.042 ¥$ & $-0.252 \dagger$ & $0.389 \dagger$ & 0.197 & \\
\hline Regional Funding & $-0.036 \dagger$ & -0.023 & 0.087 & 0.009 & \\
\hline Social Performance & $-0.021^{*}$ & -0.094 & 0.176 & 0.037 & \\
\hline Indirect Effects & & & & & \\
\hline Economic Performance & -0.001 & 0.000 & & & \\
\hline Private Funding & -0.001 & 0.001 & & & \\
\hline State Funding & $-0.041 \dagger$ & 0.034 & & & \\
\hline Regional Funding & -0.009 & 0.008 & & & \\
\hline \multirow[t]{3}{*}{ Social Performance } & -0.018 & 0.015 & & & \\
\hline & \multicolumn{5}{|c|}{ Public Group (N=153) } \\
\hline & $\begin{array}{l}\text { Financial } \\
\text { Resources }\end{array}$ & $\begin{array}{l}\text { Human } \\
\text { Resources }\end{array}$ & $\begin{array}{c}\text { Online } \\
\text { Accessibility }\end{array}$ & $\mathbf{R}^{2}$ & Goodness Fit \\
\hline \multicolumn{6}{|l|}{ Direct Effects } \\
\hline Online Accessibility & -0.038 & 0.050 & & 0.004 & \multirow{12}{*}{$\begin{array}{c}x 2[10]: 11.403 \text {, } \\
\text { Pvalue: } 0.327, \\
\text { RMSEA: } 0.038 \text {, } \\
\text { SRMR: } 0.043 \text {, } \\
\text { CFI: } 0.955\end{array}$} \\
\hline Economic Performance & 0.088 & -0.331 & $0.075 ¥$ & 0.125 & \\
\hline Private Funding & 0.081 & -0.008 & $0.022 \dagger$ & 0.007 & \\
\hline State Funding & 0.073 & -0.043 & $-0.161 ¥$ & 0.035 & \\
\hline Regional Funding & 0.077 & -0.070 & $0.045 ¥$ & 0.013 & \\
\hline Social Performance & -0.082 & 0.033 & $0.031^{*}$ & 0.010 & \\
\hline Indirect Effects & & & & & \\
\hline Economic Performance & -0.003 & 0.004 & & & \\
\hline Private Funding & -0.001 & 0.001 & & & \\
\hline State Funding & 0.006 & -0.008 & & & \\
\hline Regional Funding & -0.002 & 0.002 & & & \\
\hline Social Performance & -0.001 & 0.002 & & & \\
\hline
\end{tabular}

${ }^{*} \mathrm{p}<0.1 ; \dagger \mathrm{p}<0.05 ; ¥ \mathrm{p}<0.01$ 
Public nonprofits maintain the previous pattern of behaviour. The interrelation between online accessibility and economic and financial resources (-0.038, pvalue $>0.100)$ and human resources (0.050; pvalue>0.100) cannot be observed. However, online accessibility is linked to all of the organizational achievements variables. Public nonprofits enhance their economic performance $(0.075$; pvalue $<0.010)$ and their financial diversification, both at a private $(0.022$; pvalue $<0.050)$ and public level (0.045; pvalue< 0.010). Moreover, online accessibility is associated with the participation of a larger number of users in the social programmes developed by the nonprofit $(0.031$; pvalue $<0.100)$. However, we can observe a lower level of state funding $(-0.161$; pvalue $<0.010)$, which is due to the costs of online accessibility as part of the transparent policy of the nonprofit. Particularly, the observed negative sign reveals that if a nonprofit develops online reporting mechanisms, the entity will need to invest a part of its economic resources. This level of investment supposes that online accessibility has advantages for this type of entities. However, the nonprofit organization must support a cost for the implementation of this mechanism of reporting. In any case, these results show how, for public nonprofits, online accessibility is not a strategic element, but is only considered as a final operative aim oriented to accountability. Private nonprofits maintain a different behaviour. Financial resources have a direct impact on online accessibility $(-0.105$; pvalue $<0.010)$. The negative sign indicates that, for these entities, this transparency mechanism is a need whose origin is the decrease in financial resources on the market. These entities have a more volatile funding than public nonprofits. Thus, the lack of financial resources, especially private ones (0.997; pvalue $<0.010)$, is the element that motivates transparency for these entities. The results obtained show how the decrease in financial resources for private entities tends to generate economic activity $(-0.998$, pvalue $<0.010)$, a search for state $(-0.042$, pvalue $<0.010)$ or regional $(-0.036$, pvalue $<0.05)$ funding and a reduction of social programmes and number of users $(-0.021$; pvalue $<0.100)$. Online accessibility is understood as playing a mediating role, as an organizational capability, since it enhances the obtaining of private financial resources $(0.389$; pvalue $<0.050)$. Thus, it becomes an element of transition between the lack of financial resources and the entities' financial diversification (-0.041; pvalue $<0.050)$, ceasing to be a final aim and becoming a strategic element integrated into the management of the organization or a capability which will lead to a reduction in dependences and to the obtaining of competitive advantages.

Consequently, it is not possible to reject the proposed hypothesis, since the public or private character of the nonprofit has a positive moderating effect on the relationship between resources and organizational achievements, online accessibility being a strategic tool in private nonprofits.

\section{Discussion}

The promotion of online accessibility in nonprofit organizations has different motivations, influenced by the contextual environment (Pape et al., 2016). When there is a tendency to parcel out the provision of public social services between different organizations, increasing the uncertainty and variability of funding, as in southern European countries, the adaptation of public and private nonprofits' financial 
structure to their context is a need (Zhi, 2014). In this sense, online accessibility could be considered a strategic tool which favours the diversification of funding and the creation of value (Krishnan, Yetman and Yetman, 2006; Trussel and Parsons, 2008; Khumawala et al., 2010; Gandía, 2011).

However, online accessibility could be also considered as the answer of an organization to the needs and pressures of a society (Pasquier and Villeneuve, 2007). In recent years, there has been strong regulatory pressure in European countries through the Transparency Acts to change the role of transparent practices within organizations. As a result, online accessibility is considered an instrument oriented to accountability (Ball, 2009; Themudo, 2013; Gandía, 2011; Saxton et al., 2014) with null effects on the strategy of the entity. In the provision of public social services by nonprofits, our results show that the online accessibility is still a challenge, at least in Spain, but it is an element that can potentiate the social and economic achievements of the organization. Our results also reveal that the role of this transparency mechanism is not the same in all Spanish nonprofits related to the promotion of public social services. Some previous research has found similar results, distinguishing between the impact of transparent practices in public nonprofits (subordinate relationship) and private nonprofits (collaborative relationship). Jang and Feiock (2007) find greater pressure to integrate these practices into the organizational strategy of private nonprofits. The main reason for this is the financial need of these entities, which must compete in financial markets (Finkler et al. 2016). In contrast, public nonprofits are mainly funded by public administrations in a subordinate relationship (Liao, Foreman and Sargeant, 2001; Dolnicar et al., 2008) and could orient their online accessibility to accountability (Brinkerhoff and Brinkerhoff, 2015).

Our results confirm that, nowadays, the role of online accessibility in public nonprofits is different from private organizations in the provision of public social services (Dunleavy and Hood, 1994; Hansen and Ferlie, 2016). In Spain, there is a long way to go in the promotion of transparency mechanisms, as online accessibility, as a strategic management practice, especially in public nonprofits. Public nonprofits need to make a greater effort to integrate this kind of practices because they are wasting competitive advantages such as financial diversification. Furthermore, they should generate user trust and adopt transparent mechanisms (Grimmelikhuijsen et al., 2013). However, our results show that public and private nonprofits evolve in the same direction and that online accessibility is necessary in both cases. The use of this element will tend to converge between them, higher competitiveness leading both types of entities to obtain funds, especially in periods of public budget cuts (Funnell and Cooper, 1998).

\section{Conclusions}

Spanish public foundations are a type of nonprofit organization dedicated to the provision of public social services. They are regulated by the foundations acts and the public administration act, which defines the pillars of the provision of social services. Consequently, these entities must develop a social mission, although they should guarantee a minimum level of profit achievements 
to financially survive. This double mission, social and economic, configures these entities as social enterprises. The aim of this study was to analyse the role of online accessibility, as a tool of transparency, to integrate stakeholders' needs and maintain a reasonable level of social and economic performance.

The results reveal that the role of online accessibility, as transparency mechanism, can vary depending on the relationship between nonprofits and governments and the origin of their financial resources. Although there is a convergence process between public and private nonprofits, since both share the need to be transparent, their models of transparency are not the same. The nonprofits promoted by governments, in a subordinate relationship, identify transparency practices, as online accessibility, with accountability, while private nonprofits, with a collaborative profile with respect to governments, are more oriented to the involvement of stakeholders in the management of the entity and consider these practices as a strategic tool used to manage their relations with them. Private initiative implies the promotion of online accessibility and transparency in the obtaining of higher levels of economic and social performance and in the funding obtained by the entity. This promotion will not be seen in the case of public nonprofits because their funds depend mainly on the budget of their promoters and the level of performance is not the main criterion for budget allocation. Subordination is a dissuasive element since the cost of integrating transparency mechanisms may not be compensated by the benefits they add and, consequently, online accessibility will be considered as a resource at the same level as human or economics resources. So, public nonprofits will have little incentive to use transparency as a strategic tool and they usually consider it a legally-imposed element.

Some limitations have been detected in this study. In the measurement of online accessibility, we have only used the breadth and depth of the accounting information as measurement criteria. Furthermore, the measurement of social achievements has been linked to human resources, as there is no other public, transparent and directly comparable information. Moreover, the results obtained are based on a sample from one country and during a period of crisis. The results might change in different contexts and in different public administration styles. In this sense, the possibility of comparing between different countries would enable us to enrich this analysis and to extrapolate these conclusions to different cultural contexts. These limitations leave open future research lines such as the analysis of the steps that governments should take in the promotion of transparency mechanisms in the public nonprofit sector. It would be interesting to study other aspects that the Third Sector and governments should share in the promotion of their collaborative relationships, especially with regard to the integration of the needs of stakeholders. 


\section{References}

Andreoni, J. \& Payne, A.A. (2013). Crowding out: The effect of government grants on donors, fundraisers, and foundations in Canada. https://citeseerx.ist.psu.edu [Accessed: April 2017]

Anheier, H.K. (2014). Nonprofit organizations: An introduction: Theory, management, policy. New York: Routledge.

Anthopoulos, L. \& Sirakoulis, K. (2015). E-Government Portal Updates' Evaluation: A Comparative Analysis. In: Information Resources Management Association (Ed.), Public Affairs and Administration: Concepts, Methodologies, Tools, and Applications. England: IGI Global, pp. 2046-2064.

Aras, G. \& Crowther, D. (2008). Governance and sustainability: An investigation into the relationship between corporate governance and corporate sustainability, Management Decision, 46(3): 433-448. DOI: https://doi. org/10.1108/00251740810863870

Arnaboldi, M. \& Lapsley, I. (2004). Modern costing innovations and legitimation: a health care study. Abacus, 40: 1-20. DOI: https://doi.org/10.1111/j.1467-6281.2004.00143.x

Ball, C. (2009). What is transparency? Public Integrity, 11(4): 293-308. DOI: https://doi.org/10.2753/PIN10999922110400

Basu, S. et al. (2012). Comparative performance of private and public healthcare systems in low-and middle-income countries: a systematic review. PLoS Medicine, 9(6): e1001244. DOI: https://doi.org/10.1371/journal. pmed.1001244

Becchetti, L., Castriota, S. \& Depedri, S. (2014). Working in the for-profit versus not-for-profit sector: what difference does it make? An inquiry on preferences of voluntary and involuntary movers. Industrial and Organizational Change, 23(4): 1087-1120. DOI: https://doi.org/10.1093/icc/dtt044

Behn, B.K., DeVries, D.D. \& Lin, J. (2010). The determinants of transparency in nonprofit organizations: An exploratory study, Advances in Accounting, 26(1): 6-12. DOI: https://doi.org/10.1016/j.adiac.2009.12.001

Bellostas, A.J., López-Arceiz, F.J. \& Mateos, L. (2016). Social value and economic value in social enterprises: Value creation model of Spanish sheltered workshops. Voluntas, 27(1): 367-391. DOI: https://doi.org/10.1007/ s11266-015-9554-6

Bentler, P.M. (2006). EQS 6.1 [Computer software]. Los Angeles: Multivariate Software.

Berendes, S. et al. (2011). Quality of private and public ambulatory health care in low and middle income countries: systematic review of comparative studies, PLoS Medicine, 8(4): e1000433. DOI: https://doi.org/10.1371/journal. pmed. 1000433

Blackwood, A. (2012). The nonprofit sector in brief: Public charities, giving and volunteering. Washington DC: Urban Institute.

Bollen, K.A. (1989). A new incremental fit index for general structural equation models, Sociological Methods \& Research, 17(3): 303-316. DOI: https://doi.org/10.1177/0049124189017003004

Brinkerhoff, J.M. (2002). Government-nonprofit partnership: A defining framework, Public Administration and Development, 22(1): 19-30. DOI: https://doi.org/10.1002/pad.203

Brinkerhoff, D.W. \& Brinkerhoff, J.M. (2015). Public sector management reform in developing countries: perspectives beyond NPM orthodoxy, Public Administration and Development, 35(4): 222-237. DOI: https://doi.org/10.1002/ pad.1739

Bushman, R.M., Piotroski, J.D. \& Smith, A.J. (2004). What determines corporate transparency? Journal of Accounting Research, 42(2): 207-252. DOI: https://doi.org/10.1111/j.1475-679X.2004.00136.x

Carnochan, S. et al. (2014). Performance measurement challenges in nonprofit human service organizations, Nonprofit and Voluntary Sector Quarterly, 43(6): 1014-1032. DOI: https://doi.org/10.1177/0899764013508009

Dart, R. (2004). Being 'business-like' in a nonprofit organization: a grounded and inductive typology. Nonprofit and Voluntary Sector Quarterly, 33: 290-310. DOI: http://doi.org/10.1177/0899764004263522 
Dolnicar, S., Irvine, H. \& Lazarevski, K. (2008). Mission or money? Competitive challenges facing public sector nonprofit organisations in an institutionalised environment, International Journal of Nonprofit and Voluntary Sector Marketing, 13(2): 107-117. DOI: http://doi.org/10.1002/nvsm.311

Dunleavy, P. \& Hood, C. (1994). From old public administration to new public management, Public Money \& Management, 14(3): 9-16. DOI: http://doi.org/10.1080/09540969409387823

Emerson, J. (2006). Moving ahead together: Implications of a blended value framework for the future of social entrepreneurship. In: Nicholls, A. (Ed.) Social Entrepreneurship, New Models of Sustainable Social Change. Oxford University Press: pp. 391-406.

Evers, A. \& Laville, J.L. (Eds.). (2004). The third sector in Europe. UK: Edward Elgar Publishing.

Finkler, S.A. et al. (2016). Financial management for public, health, and not-for-profit organizations. New York: Pearson.

Fornell, C. \& Larcker, D.F. (1981). Evaluating structural equation models with unobservable variables and measurement error, Journal of Marketing Research, 18(1): 39-50. DOI: http://doi.org/10.2307/3151312

Funnell, W. \& Cooper, K. (1998). Public sector accounting and accountability in Australia. Australia: UNSW Press.

Gallego-Álvarez, I., García-Sánchez, I. \& Rodríguez-Domínguez, L. (2008). Voluntary and compulsory information disclosed online: the effect of industry concentration and other explanatory factors, Online Information Review, 32(5): 596-622. DOI: http://doi.org/10.1108/14684520810913990

Gálvez-Rodríguez, M.M., Caba-Perez, C. \& López-Godoy, M. (2014), Drivers for the proactive online disclosure of information in the NGO sector: the Colombian case. Online Information Review, 38(6): 769-787. DOI: http:// doi.org/10.1108/OIR-05-2014-0113

Gandía, J.L. (2008). Determinants of interest-based corporate governance disclosure by Spanish listed companies, Online Information Review, 32(6): 791-817. DOI: http://doi.org/10.1108/14684520810923944

Gandía, J.L. (2011). Internet disclosure by nonprofit organizations: Empirical evidence of nongovernmental organizations for development in Spain, Nonprofit and Voluntary Sector Quarterly, 40(1): 57-78. DOI: http://doi. org/10.1177/0899764009343782

Gandía, J.L., Marrahí, L. \& Huguet, D. (2016). Digital transparency and web 2.0 in Spanish city councils, Government Information Quarterly, 33(1): 28-39. DOI: https://doi.org/10.1016/j.giq.2015.12.004

Glassey O. \& Glassey, O.F. (2004). A proximity indicator for e-Government: The smallest number of clicks, Journal of e-Government, 1(4): 5-20. DOI: http://doi.org/10.1300/J399v01n04_02

Grimmelikhuijsen, S. et al. (2013). The effect of transparency on trust in government: A cross-national comparative experiment, Public Administration Review, 73(4): 575-586. DOI: https://doi.org/10.1111/puar.12047

Hamann, D.J. \& Foster, N.T. (2014). An exploration of job demands, job control, stress, and attitudes in public, nonprofit, and for-profit employees, Review of Public Personnel Administration, 34(4): 332-355. DOI: https:// doi.org/10.1177/0734371X13491119

Hansen, J.R. \& Ferlie, E. (2016). Applying strategic management theories in public sector organizations: Developing a typology, Public Management Review, 18(1): 1-19. DOI: http://doi.org/10.1080/14719037.2014.957339

Haveri, A. (2006). Complexity in local government change: Limits to rational reforming, Public Management Review, 8(1): 31-46. DOI: http://doi.org/10.1080/14719030500518667

Hayes, A.F. (2013). Introduction to mediation, moderation, and conditional process analysis: A regression-based approach. USA: Guilford Press.

Henriksen, L. (2007). The diversity of government-nonprofit relations - Selected cases from Danish social policy. Paper presented at International Research Society for Public Management, Potsdam, Germany.

Hungerman, D.M. (2005). Are church and state substitutes? Evidence from the 1996 welfare reform. Journal of Public Economics, 89(11): 2245-2267. DOI: https://doi.org/10.1016/j.jpubeco.2004.12.009

Irvine, H. (2000). Powerful friends: the institutionalization of corporate accounting practices in an Australian religious/ charitable organisation, Third Sector Review, 6(1-2): 5-26. 
Jang, H.S. \& Feiock, R.C. (2007). Public versus private funding of nonprofit organizations: Implications for collaboration, Public Performance \& Management Review, 31(2): 174-190. DOI: https://doi.org/10.2753/PMR15309576310202

Josserand, E., Teo, S. \& Clegg, S. (2006). From bureaucratic to post-bureaucratic: The difficulties of transition, Journal of Organizational Change Management, 19: 54-64. DOI: https://doi.org/10.1108/09534810610643686

Kang, C. et al. (2014). Turnover and retention in nonprofit employment the Korean college graduates' experience, Nonprofit and Voluntary Sector Quarterly, 44(4): 641-664. DOI: https://doi.org/10.1177/0899764014553032

Khumawala, S.B., Neely, D.G. \& Gordon, T.P. (2010). The impact of voluntary disclosures on charitable giving. American Accounting Association Working paper.

Kosack, S. \& Fung, A. (2014). Does transparency improve governance? Annual Review of Political Science, 17: 65-87. DOI: https://doi.org/10.1146/annurev-polisci-032210-144356

Kramer, R. (1992). Voluntary organizations, contracting and the welfare state. In: Batsleer J., Cornforth, C., \& Paton, R. (Eds.), Voluntary and Nonprofit Sector. Addison: Wesley England, pp. 181-191.

Krishnan, R., Yetman, M.H. \& Yetman, R.J. (2006). Expense misreporting in nonprofit organizations. Accounting Review, 81: 399-420. DOI: https://doi.org/10.2308/accr.2006.81.2.399

Kuhnle, S. \& Selle, P. (1990). Meeting needs in a welfare state: Relations between government and voluntary organizations in Norway. In: Ware, A., Goodin, R. (Eds.), Needs and welfare, pp. 165-184. USA: SAGE.

Ley 50/2002, de 26 de diciembre, de Fundaciones. Boletín Oficial del Estado-BOE, núm.310, de 27 de diciembre de 2002, páginas 45504 a 45515 .

Liao, M.N., Foreman, S. \& Sargeant, A. (2001). Market versus societal orientation in the nonprofit context. International Journal of Nonprofit and Voluntary Sector Marketing, 6, pp. 254-268. DOI: https://doi.org/10.1002/nvsm.151

López-Arceiz, FJ., Bellostas, A.J. \& Rivera, M.P. (2017). Accessibility and transparency: impact on social economy, Online Information Review, 41(1): 35-52. DOI: https://doi.org/10.1108/OIR-09-2015-0296

López-Arceiz, F.J., Torres, L. \& Bellostas, A.J. (2019). Is online disclosure the key to corporate governance? Online Information Review. DOI: https://doi.org/10.1108/OIR-06-2018-0191

McDonald, R.P. (1989). An index of goodness-of-fit based on noncentrality, Journal of Classification, 6(1): 97-103. DOI: https://doi.org/10.1007/BF01908590

Marcuello, C. \& Salas, V. (2001). Nonprofit organizations, monopolistic competition, and private donations: Evidence from Spain, Public Finance Review, 29(3): 183-207. DOI: https://doi.org/10.1177/109114210102900301

Mano, R. (2014). Networking Modes and Performance in Israel Nonprofit Organizations, Nonprofit Management \& Leadership, 24(4): 429-444. DOI: https://doi.org/10.1002/nml.21104

Mano, R. (2015). Funding Allocations in Israel: An Empirical Assessment of the New Philanthropy Approach, Voluntas, 26(5): 2130 -2145. DOI: https://doi.org/10.1007/s11266-014-9495-5

Moneva, J.M., Ortas, E. (2010). Corporate environmental and financial performance: a multivariate approach. Industrial Management \& Data Systems, 110(2): 193-210. DOI: https://doi.org/10.1108/02635571011020304

Muthén, L.K., Muthén, B.O. (1998-2015), Mplus user's guide, 7. Los Angeles: Statmodel.

Myers, J. \& Sacks, R. (2003). Tools, techniques and tightropes: the art of walking private sector management in nonprofit organisations, is it just a question of balance? Financial Accountability \& Management, 19: 287-305. DOI: https://doi.org/10.1111/1468-0408.00175

Neumayr, M., Schneider, U. \& Meyer, M. (2013). Public funding and its impact on nonprofit advocacy, Nonprofit and Voluntary Sector Quarterly, 44(2): 297-318. DOI: https://doi.org/10.1177/0899764013513350

Overman, S. \& Van Thiel, S. (2016). Agencification and public sector performance: A systematic comparison in 20 countries, Public Management Review, 18(4): 611-635. DOI: http://doi.org/10.1080/14719037.2015.1028973 
Pape, U. et al. (2016). Working under pressure: economic recession and third sector development in Europe. International Journal of Sociology and Social Policy, 36(7-8): 547-566. DOI: http://doi.org/10.1108/IJSSP-01-2016-0010

Pasquier, M. \& Villeneuve, J.P. (2007). Organizational barriers to transparency a typology and analysis of organizational behaviour tending to prevent or restrict access to information, International Review of Administrative Sciences, 73(1): 147-162. DOI: http://doi.org/10.1177/0020852307075701

Porter, M. et al. (2012). Measuring shared value: How to unlock value by linking social and business results. USA: FSG.

Preacher, K.J., Rucker, D.D. \& Hayes, A.F. (2007). Addressing moderated mediation hypotheses: Theory, methods, and prescriptions, Multivariate Behavioral Research, 42(1): 185-227. DOI: https://doi. org/10.1080/00273170701341316

Rosenthal, G. \& Newbrander, W. (1996). Public policy and private sector provision of health services, International Journal of Health Planning and Management, 11: 203-216. DOI: https://doi.org/10.1002/(SICI)10991751(199607)11:3\%3C203::AID-HPM432\%3E3.0.CO;2-0

Salamon, L.M. (1987). Of market failure, voluntary failure, and third-party government: Toward a theory of governmentnonprofit relations in the modern welfare state, Nonprofit and Voluntary Sector Quarterly, 16(1-2): 29-49. DOI: https://doi.org/10.1177/089976408701600104

Salamon, L.M. \& Sokolowski, W. (2014), The third sector in Europe: Towards a consensus conceptualization, Working Paper, European Union. http://thirdsectorimpact.eu [Accessed 22 April, 2017]

Sarasa, S. \& Moreno, L. (Eds.). (1995). The welfare state in southern Europe. Spain: CSIC-CSIC Press.

Satorra, A. \& Bentler, P.M. (2001). A scaled difference chi-square test statistic for moment structure analysis, Psychometrika, 66(4): 507-514. DOI: https://doi.org/10.1007/BF02296192

Saxton, G.D. \& Guo, C. (2011). Accountability online: Understanding the web-based accountability practices of nonprofit organizations, Nonprofit and Voluntary Sector Quarterly, 40: 270-295. DOI: https://doi. org/10.1177/0899764009341086

Saxton, G.D., Neely, D.G. \& Guo, C. (2014). Web disclosure and the market for charitable contributions, Journal of Accounting and Public Policy, 33(2): 127-144. DOI: https://doi.org/10.1016/j.jaccpubpol.2013.12.003

Schnackenberg, A.K. \& Tomlinson, E.C. (2014). Organizational transparency: A new perspective on managing trust in organization-stakeholder relationships, Journal of Management, (published online). DOI: https://doi. org/10.1177/0149206314525202

Schneider, U. \& Hagleitner, J. (2005). Österreichische NPO im Spiegel der Arbeitsstättenzählung 2001 [Situation of Austrian NPO sector in 2001], Forschungsberichte des Institutsfür Sozialpolitik 02/2005, Wirtschaftsuniversität Wien, Wien.

Scott, K. (2003). Funding matters: The impact of Canada's new funding regime on nonprofit and voluntary organizations. Ottawa: Canadian Council on Social Development.

Sieg, H. \& Zhang, J. (2012). The effectiveness of private benefits in fundraising of local charities, International Economic Review, 53(2): 349-374. DOI: https://doi.org/10.1111/j.1468-2354.2012.00684.x

Sutheewasinnon, P., Hoque, Z. \& Nyamori, R.O. (2016). Development of a performance management system in the Thailand public sector: Isomorphism and the role and strategies of institutional entrepreneurs, Critical Perspectives on Accounting, 40: 26-44. DOI: https://doi.org/10.1016/j.cpa.2015.06.002

Themudo, N.S. (2013). Reassessing the impact of civil society: nonprofit sector, press freedom, and corruption, Governance, 26(1): 63-89. DOI: https://doi.org/10.1111/j.1468-0491.2012.01602.x

Tinkelman, D. (1999). Factors affecting the relation between donations to not-for-profit organizations and an efficiency ratio, Research in Government and Nonprofit Accounting, 10: 135-161.

Torres, L. \& Pina, V. (2003).Accounting for Accountability and Management in NPOs. A Comparative Study of Four Countries: Canada, the United Kingdom, the USA and Spain. Financial Accountability and Management, 19(3): 265-285. DOI: https://doi.org/10.1111/1468-0408.00174 
Treaty on European Union and the treaty on the functioning of the European Union (TFEU) (2012) 2012/C 326/01.

Trussel, J.M. \& Parsons, L.M. (2008). Financial reporting factors affecting donations to charitable organizations. Advances in Accounting, 23: 263-285. DOI: https://doi.org/10.1016/S0882-6110(07)23010-X

Van Thiel, S. (2012). Comparing agencies across countries. In: Verhoest, K., Thiel, S.V., Bouckaert, G., Lægreid, P.,Government agencies: Practices and lessons from 30 countries. New York: Palgrave Macmillan, pp.18-26. DOI: https://doi.org/10.1057/9780230359512_2

Verschuere, B. \& De Corte, J. (2015). Nonprofit advocacy under a third-party government regime: Cooperation or conflict? Voluntas, 26(1): 222-241. DOI: https://doi.org/10.1007/s11266-013-9427-9

Zaphiris, P. \& Mtei, L. (1997). Depth vs breadth in the arrangement of web links. USA: Arrangement Web Links.

Zeldman, J. (2001). Takingyour talent to the web: A guide for the transitioning designer, Indianapolis: New Riders Publishing.

Zhi, L. (2014). The congestion of local public service and the optimization of financial structure in China, Finance \& Economics, 5: 013. 